\title{
CORRELATION BETENGAN TRADITIONAL GAMES ON LOCOMOTOR MOVEMENTS AND CHARACTERS
}

\author{
Ika Ari Pratiwi ${ }^{1}$, dan Mohammad Syaffruddin Kuryanto ${ }^{2}$ \\ ${ }^{1,2}$ Pendidikan Guru Sekolah Dasar, Universitas Muria Kudus \\ Email: $\underline{\text { kka.ari@umk.ac.id ; Syafruddin.kuryanto@umk.ac.id }}$
}

\begin{tabular}{|c|}
\hline Info Artikel \\
\hline $\begin{array}{l}\text { Sejarah Artikel: } \\
\text { Diserahkan 12 September } 2019 \\
\text { Direvisi 11 November } 2019 \\
\text { Disetujui } 18 \text { November } 2019\end{array}$ \\
\hline $\begin{array}{l}\text { Keywords: } \\
\text { betengan traditional games, } \\
\text { locomotor motion, friendly } \\
\text { character }\end{array}$ \\
\hline
\end{tabular}

\begin{abstract}
The purpose of this study is to determine the positive correlation between traditional games with student movements and friendly characters.

The study was conducted at SD Muhammadiyah 1 Kudus. Research methods using a quantitative correlational approach. The research sample consisted of 29 students. This research technique is collecting observation data, analyzed using Pearson product-moment correlation test with prerequisite linearity and normality tests.

The results showed that the data met the prerequisite test with a significance of linearity of 0.898 and the significance of normality of 0.20 . Obtained results of the coefficient significance of traditional game betengan with the locomotor motion of $0.708>0.5$ and with a very strong correlation category level. On the other hand, there is a significant coefficient of correlation betengan traditional games with friendly characters of 0.702> 0.05 with a very strong level. So the results of traditional game betengan research have a strong correlation with locomotor motion and student-friendly character.
\end{abstract}

\begin{abstract}
Abstrak
Tujuan penelitian ini yaitu untuk mengetahui korelasi positif permainan tradisional betengan dengan gerak siswa dan karakter bersahabat.

Penelitian dilakukan di SD Muhammadiyah 1 Kudus. Metode penelitian dengan menggunakan kuantitatif berpendekatan korelasional. Sampel penelitian ini berjumlah 29 siswa. Teknik penelitian ini yaitu pengumpulan data observasi, dianalisis menggunakan uji korelasi product moment Pearson dengan uji prasyarat linearitas dan normalitas.

Hasil penelitian menunjukkan bahwa data memenuhi uji prasyarat dengan signifikansi linearitas 0,898 dan signifikansi normalitas 0,20 . Diperoleh hasil koefisien signifikansi korelasi permainan tradisional betengan dengan gerak lokomotor sebesar $0,708>0,5$ dan dengan tingkat kategori korelasi yang sangat kuat. Di sisi lain terdapat koefisien signifikansi korelasi permainan tradisional betengan dengan karakter bersahabat sebesar $0,702>0,05$ dengan tingkat yang sangat kuat. Maka hasil penelitian permainan tradisional betengan memiliki korelasi kuat terhadap gerak lokomotor dan karakter bersahabat siswa.
\end{abstract}

(C) 2019 Universitas Muria Kudus 
Ika Ari Pratiwi, dan Mohammad Syaffruddin Kuryanto

HUBUNGAN PERMAINAN TRADISIONAL BETENGAN TERHADAP GERAK LOKOMOTOR ... REFLEKSI EDUKATIKA : Jurnal Ilmiah Kependidikan 10 (1) Desember 2019. Hlm. 71-76

\section{INTRODUCTION}

Growth and development is a process that goes on as a child ages. But growth and development encompass two events that are distinct but interrelated and difficult to separate. Growth and development is a process of change that occurs in every living thing. One example is the development of children's play. Children's games are now more passive and do not encourage the body to move actively and socialize with peers directly. This causes changes in the pattern of growth of children both psychological, emotional, and social child.

Traditional games are the result of the creativity of children who are in a certain area. Traditional games also contain a variety of values contained therein, including educational values, togetherness, and familiarity. This is caused by traditional games always done together. One such game is the traditional game betengan. Betengan game is a game that has the aim of the game to take the opponent's castle. In line with the opinion of Nurastuti (2012) Betengan game is a game handed down from generation to generation, the maker is no longer known and the way to play is to take the opponent's castle. with these games encourage students to move together. As explained by Huda (2016) Through playing games can improve children's social skills such as cooperation, communication, sharing, participation, and aspects of adaptation. Besides that, traditional games have various noble values in them. Ardiwinata et al, in Nurastuti (2012) traditional games betengan contained noble values, including cooperation in groups, honesty, patience, careful strategic planning, and effective communication.

According to the type of activity, traditional games can be divided into 2: active games and passive games (Khobir, 2009) Furthermore Yanti (2014) explains that active games are activities that involve physical activities that cause feelings of pleasure in children where these play activities can be done alone or together with friends and can be done in life so as to provide stimulation for the development of children. While the child's passive play does not move the body much, it's just more impressed that the child's soul is actively playing through the senses he has.

In traditional games, students are actively chasing opponents and saving friends. With active play, children will feel happy because playing together with their peers. Unconsciously students will move their bodies to move to a place to win the traditional game. So indirectly traditional games can encourage children to learn the locomotor motion. Suhendrik (2011) also explained that traditional game betengan is a type of game that requires high activity. So the locomotor motion learned by children becomes a lot, such as walking, running, and jumping. In line with the opinion of Sugiyanto in Argasasmita (2007) explains that locomotor motion is the movement of moving from one place to another. For example walking, running, jumping, and so on.

Betengan traditional game is a game that represents war to seize the opponent's fortress by incorporating existing local wisdom. The game is named according to how to play, namely by taking the opponent's beteng. Husna (2009) how to play the traditional game betengan are as follows: a) Groups of students are divided into two groups b) Each group chooses posts such as trees, poles, or chairs as their strongholds, c) The task of each group is to take the opponent's beteng, d) Each player must touch his post or fort to renew his strength, e) Players who have been captured will be enemy captives and imprisoned next to the opponent's fortress, f) Players who are captured can then be saved if touched by a groupmate, and g) A winning group is a group who can seize the opponent's castle by touching the opponent's castle. Betengan games require two teams to be played. In the game, students are required to work together to arrange strategies to be able to touch the opponent's stronghold. So to win this game, students must be able to collaborate with friends to fish, chase, and outwit the opponent to be able to seize the opponent's castle.

Betengan traditional games that have the nature of active games encourage students to learn motion during the game. In other words, students learn Motor Learning. Motor (motion) is a term that is often used for various kinds of human motion. Rider (Kiram 2019) explains that motor learning (motion) is a process of improving motor coordination abilities, through the optimization of external and internal requirements factors that aim to gain/master certain skills, abilities, and behavior. Traditional games can directly develop fundamental movement skills. In the study of Aristha (2014) shows that there is a significant influence of traditional games on the fundamental movement skills of elementary school students.

The game is laden with skill in motion. The achievement of skill is influenced by many factors. Likewise, the process of learning motion. 
Ika Ari Pratiwi, dan Mohammad Syaffruddin Kuryanto

HUBUNGAN PERMAINAN TRADISIONAL BETENGAN TERHADAP GERAK LOKOMOTOR ... REFLEKSI EDUKATIKA : Jurnal Ilmiah Kependidikan 10 (1) Desember 2019. Hlm. 71-76

Dicaprio (2017) suggests things that affect the mastery of skills including, learning process factors, personal factors of students who learn, and situation factors. Broadly speaking, motor learning in schools includes gross and fine motor skills. Gross motor is a body movement that uses large muscles or some muscles in the body that are affected by self maturity. Meanwhile fine motor is a movement carried out by certain body parts and only involves a portion of the body's muscles. Most of the motion in the game is bent using large muscles. So the Bentengan game is gross motor learning.

The traditional bentengan game contains elements of friendly character values to get the students to get along together. So that the game can make it easier for teachers to instill friendly characters in learning, especially for grade 4 students. Agreeing with Hamidi (2018) children's social competence can be improved by encouraging children to participate in their social environment. So that the traditional game has a social feel and involves interaction with peers. Setyorini (2016) states that at that age children enter high class, so at that time children like to form their peers.

This game requires teamwork to be able to defend the castle from enemy captives, with elements of friendly character values, namely: a) formulating strategies with team members, b) communicating with team members, c) helping team members, cohesiveness towards victory. This causes the traditional game to have various noble values, including teamwork, honesty, patience, careful strategic planning, and effective communication. Ardiwinata, et al (Nurastuti 2012).

Traditional games encourage students to have good social competence. From Susanti's research (2010) in SDN Srondol Wetan, children who are liked by friends have academic excellence are also considered to have good and friendly nature by their other peers.

\section{RESEARCH METHODS}

This research is a correlation study with a bivariate correlation approach to describe the correlation between three variables. The sampling technique in this study is the sampling technique saturated with the number of 29 students. The independent variable of this study is locomotor motion and friendly character. While the dependent variable of this study is the traditional game betengan. The data collection technique of this research is observation. The flow of this research are: 1) Analysis 2)
Instrumentation 3) Testing the validity and reliability 4) Instrument revision 5) Research 6) Data collection 7) Data analysis 8) Results.

In this study, researchers analyzed locomotor motion observation data, friendly ability data, and betengan game observation data. The locomotor motion observation indicators in this study are the motion of walking, running and jumping. Indicators of friendly ability are students able to communicate well, good listeners, respect for others, can cooperate, and attention to others. Traditional game indicators with observational data are student activeness data chasing enemies, searching for strength, waiting for fortresses, saving friends, and attacking the opponent's fortresses. The results of the observational data were analyzed using the Pearson product-moment correlation analysis method. The prerequisite test for using Pearson product-moment correlation is that the data measured has a normal distribution and is homogeneous that has the same variant (Husaini and Purnomo, 2003)

\section{RESULT AND DISCUSSION}

According to the results of observations, the results of the research can be explained. The observation analysis obtained by the researchers is as follows:

\begin{tabular}{|c|c|c|c|c|}
\hline \multicolumn{5}{|c|}{ Correlations } \\
\hline & & $x$ & $\mathrm{y} 1$ & $\mathrm{y} 2$ \\
\hline \multirow[t]{3}{*}{$x$} & Pearson Correlation & 1 & ,708* &, $702^{* *}$ \\
\hline & Sig. (2-tailed) & &, 000 &, 000 \\
\hline & $\mathrm{N}$ & 29 & 29 & 29 \\
\hline \multirow[t]{3}{*}{ y1 } & Pearson Correlation & ,708** & 1 &, $872^{* *}$ \\
\hline & Sig. (2-tailed) &, 000 & &, 000 \\
\hline & $\mathrm{N}$ & 29 & 29 & 29 \\
\hline \multirow[t]{3}{*}{ y2 } & Pearson Correlation &, $702^{* *}$ & $872^{* *}$ & 1 \\
\hline & Sig. (2-tailed) &, 000 &, 000 & \\
\hline & $\mathrm{N}$ & 29 & 29 & 29 \\
\hline
\end{tabular}

**. Correlation is significant at the 0.01 level (2-tailed).

From the observations, it can be seen that traditional games have a positive relationship with locomotor motion. In the calculation of Pearson product, moment correlation gets a significance of 0.708 which can be interpreted as traditional games to have a strong relationship with locomotor motion. Similarly, traditional games betengan with friendly abilities. Getting a 
Ika Ari Pratiwi, dan Mohammad Syaffruddin Kuryanto

HUBUNGAN PERMAINAN TRADISIONAL BETENGAN TERHADAP GERAK LOKOMOTOR ... REFLEKSI EDUKATIKA : Jurnal Ilmiah Kependidikan 10 (1) Desember 2019. Hlm. 71-76

significance of 0.702 which can be interpreted as traditional games betengan to have a strong relationship with friendly abilities. The simple explanation is based on the correlation coefficient value of Guilford Empirical Rules in (Sambas and Maman, 2009) as follows: 0.00 $<0.2$ very weak relationships; weak relationship; sufficient relationship; strong relationship; and the relationship is very strong. Before the data is tested using Pearson's product-moment correlation, the data to be measured is tested for its linearity and normality prerequisites. The results of the prerequisite test showed that the observation data fulfilled the prerequisites with a linearity significance of 0.898 , and a sign of normality of 0.20 . Linearity and homogeneity tests show $>0.05$, which means linear and normal observational data. If the data shows linear means that if the better the students play, the locomotor motion and the friendliness of the students are better. The following is a description of the observation data.

\begin{tabular}{lr|r|r|r|r} 
& & & & \\
& & & & & \multicolumn{1}{c}{ Std. } \\
& $\mathrm{N}$ & $\mathrm{m}$ & $\mathrm{m}$ & $\mathrm{n}$ & \multicolumn{1}{c}{$\mathrm{n}$} \\
\hline bentenga & 2 & 17 & 68 & 40,5 & 14,299 \\
\hline $\mathrm{n}$ & 9 & & & 9 & \\
\hline locomotor & 2 & 14 & 56 & 28,8 & 11,451 \\
& 9 & & & 6 & \\
\hline friendly & 2 & 14 & 37 & 25,8 & 7,305 \\
& 9 & & & 3 & \\
\hline Valid N & 2 & & & & \\
\hline (listwise) & 9 & & & & \\
\hline
\end{tabular}

Based on the data exposure, the results of the study show that the research hypothesis which states that there is a positive relationship between the traditional game of betengan and locomotor motion is acceptable. The correlation coefficient of 0.708 indicates that there is a positive and significant relationship between traditional games and locomotor motion, as in Pahlawati (2017), traditional game activities can increase students' locomotor motion abilities. Students in indirectly free to move the body. Betengan traditional game has a lot of locomotor motion contained in it.

Traditional game betengan, locomotor movements are walking, running, and also jumping. Suhendrik (2011) states that traditional game betengan is a type of game that requires high activity. Based on observations, the locomotor motion has a mean of 28 , which means that at least every student made a walking, running and jumping motion 28 movements in one game. This encourages the student body to actively learn natural movements, especially the motion needed to be able to win the traditional Betengan game. The more proficient students play traditional games, the better the locomotor movement of students.

The traditional game is a vehicle for children to explore, rejoice with their friends. The traditional game played by 2 teams of several children in an open environment without limited space is a Bentengan game. Kuryanto (2018) suggested a competitive playing game to fight the opponent's fortress. Efforts to win the fortress opponent requires intimacy and cooperation in establishing team cohesiveness. This can be seen in the application of friendly characters possessed by each child.

Based on the description it can be concluded that the traditional game betengan has a positive relationship with locomotor motion. Betengan traditional games can encourage students to learn motion naturally by trying to win the game. The more proficient students play traditional games, the better the locomotor motion of students. The results of this study have similarities and differences with Andriani (2012), Bekti (2015), Agustini (2016), Nurhayati (2012), Irman (2017), Saputra (2017), Kuryanto (2018), Candra (2018), Yudawinata (2018) 2014), and Wulan (2015). The similarity is in traditional games and locomotor motion as research variables. Meanwhile, the differences are in the focus of the research and the methods so that the results of the research are different.

\section{CONCLUSION}

Based on the observations and results of the study in the study "The Relationship of Betengan Traditional Games Against Locomotor Motion and friendly characters" it can be concluded that the traditional game betengan has a positive relationship with increasing locomotor motion and student-friendly characters, so that students who play traditional game betengan can indirectly improve locomotor mobility and friendly character that students have. So, in this case, it requires the teacher, parents, and the community closest to students to actively use the traditional game betengan. 
Ika Ari Pratiwi, dan Mohammad Syaffruddin Kuryanto

HUBUNGAN PERMAINAN TRADISIONAL BETENGAN TERHADAP GERAK LOKOMOTOR ... REFLEKSI EDUKATIKA : Jurnal Ilmiah Kependidikan 10 (1) Desember 2019. Hlm. 71-76

In the research, the results obtained a significance coefficient of 0.708 greater than 0.05 or $0.708>0.5$ and with a very strong correlation category level. On the other hand, there is a significant coefficient of 0.702 greater than 0.05 with a very strong level and this indicates that the correlation between traditional games has a strong correlation with locomotor motion and student-friendly character.

\section{REFERENCES}

Agrasasmita, H. 2007. Teori Kepelatihan Dasar. Jakarta: Kementrian Negara Pemuda dan Olahraga.

Agustini, Ikee Proklamasi., Tomi, Agus., dan Sudjana, I Nengah. 2016. Peningkatan Keterampilan Gerak Dasar Lokomotor Menggunakan Metode Bermain Dalam Pembelajaran Pendidikan Jasmani Siswa Kelas III C SDN Krian 3 Kabupaten Sidoarjo. PENDIDIKAN JASMANI, 26 (02): 229-237.

Andriani, Tuti. 2012. Permainan Tradisional Dalam Membentuk Karakter Anak Usia Dini. Jurnal Sosial Budaya, 9 (1): 121136

Bekti, R.., dan Himawanto, W. 2015. Pengaruh Pembelajaran Lokomotor Terhadap Kemampuan Motorik Pada Anak Kelas I Tunagraita (C1) SLB Putera Asih Kota Kediri. Efektor, 2 (2).

Candra, Juli. 2018 Peningkatan Hasil Belajar Gerak Lokomotor Dengan Pola Pendekatan Bermain SD Al Hanief Kota Bekasi. Jendela Olahraga, 3 (1): 57-66.

Dicaprio, R. 2017. Panduan Mengembangkan Kecerdasan Motorik Siswa. Yogyakarta: Diva Press.

Hamidi, Marzoan. 2017. Permainan Tradisional Sebagai Kegiatan Ekstrakurikuler Untuk Meningkatkan Kompetensi Sosial Siswa. Journal An-nafs: 02 (1): 62-82

Huda, K. 2016. Peningkatan Keterampilan Sosial Melalui Bermain Beteng-betengan. Realita Jurnal Bimbingan dan Konseling, 153-163.
Husaini, dan Purnomo. 2003. Pengantar Statistika. Jakarta: Sinar Grafika.

Husna. 2009. 100+ Permainan Tradisional Indonesia untuk Kreativitas. Yogyakarta: ANDI Yogyakarta.

Irman,. Irman. 2017. Nilai-Nilai Karakter pada Anak Dalam Permainan Tradisionan dan Moderen. Konseling (Jurnal Bimbingan dan Konseling), 04 (2): 89-96.

Khoir, Abdul. 2009. Upaya Mendidik Anak Melalui Permainan Edukatif. Forum Tarbiyah, 07 (2): 195-208

Kiram, P. Y. 2019. Belajar Keterampilan Motorik. Jakarta: Prenada Media Group.

Kuryanto, M,.S dan Pratiwi, I,.A. 2018. Hubungan Permainan Tradisional Betengan Terhadap Gerak Lokomotor Siswa. Jurnal Prakarsa Paedagogia, 1 (2):133 - 138

Lestari, Indah. 2014. Pengembangan Media Bimbingan Dan Konseling Berbasis Islami Untuk Membentuk Karakter Mandiri Anak Usia Dini. Refleksi Edukatika : Jurnal Ilmiah Kependidikan, 4 (1): $1-5$.

Nurastuti, M. F., K, S. M., dan Yuliadi, I. 2015. Pengaruh Permainan Tradisional Bentengan Terhadap Interaksi Sosial Anak Asuh di Panti Yatim Hajah Maryam Kalibeber Wonosobo. Wacana: Jurnal Psikologi, 1-14.

Nurhayati, Iis. 2012 Peran Permainan Tradisional Dalam Pembelajaran Anak Usia Dini (Studi di PAUD Geger Sunten, Desa Suntenjaya). Jurnal EMPOWERMENT, 1 (2): 39-48.

Pahlawati, I. S. 2018. Upaya Meningkatkan Kemampuan Gerak Dasar Lokomotor Melalui Pembelajaran Permainan Tradisional Bentengan (Thesis). Bandung: Fakultas Pendidikan Olahraga dan Kesehatan Universitas Pendidikan Indonesia.

Saputra, Nofrans Eka dan Ekawati, Yun Nina. 2017. Permainan Tradisional Sebagai Upaya Meningkatkan Kemampuan Dasar 
Ika Ari Pratiwi, dan Mohammad Syaffruddin Kuryanto

HUBUNGAN PERMAINAN TRADISIONAL BETENGAN TERHADAP GERAK LOKOMOTOR ...

REFLEKSI EDUKATIKA : Jurnal Ilmiah Kependidikan 10 (1) Desember 2019. Hlm. 71-76

Anak. Jurnal Psikologi Jambi, 2 (2): 4853.

Setyorini, D., \& Izzaty, R. E. 2016. Pengembangan Perangkat Pembelajaran Untuk Meningkatkan Motivasi Belajar dan Karakter Bersahabat Siswa Kelas IV SD. Jurnal Prima Edukasia, 120-133.

Suhendrik, R. B. 2011. Pengembangan Model Pembelajaran Permainan Tradisional Betengan Pada Siswa Kelas Tinggi Di SD Negeri Sidakangen Kecamatan Kalimanah Kabupaten Purbalingga Tahun Ajaran 2010/2011 (Skripsi). Semarang: Fakultas Ilmu Keolahragaan Universitas Negeri Semarang.
Susanti, Fitria. 2010. Pengaruh Permainan Tradisional Terhadap Kompetensi Interpersonal Dengan Teman Sebayanya Pada Siswa SD. Jurnal Psikologi UNDIP. 08 (2): 145-152.

Wulan, Dwi Septi Anjas. 2015. Peningkatan Kemampuan Gerak Lokomotor Melalui Permainan Lari Estafet Modifikasi (Penelitian Tindakan di TK B Jihan Ulfani Kecamatan Medan Marelan Tahun 2014/2015). Jurnal Pendidikan Usia Dini, 9 (1): 163-180.

Yanti, N. I. 2014. Pengaruh Permainan Aktif Kreativitas Pada Penguasaan Konsep Matematika Awal. Jurnal Pendidikan Usia Dini, 1-12.

Yudiwinata, Hikmah Prisia dan Handoyo, Pambudi. 2014. Permainan Tradisional Dalam Budaya dan Perkembangan Anak. Paradigma, 2 (3): 1-5 